\title{
Pyritized diatoms: a good fossil marker in the Upper Paleocene-Lower Eocene sediments from the Belgian and Dieppe-Hampshire Basins
}

\author{
Y. Van Eetvelde ${ }^{1}$, C. Dupuis ${ }^{2} \&$ C. Cornet ${ }^{3}$
}

1 Département de géologie, F.U.N.D.P., 61 rue de Bruxelles, B-5000 Namur, Belgium, yoann.vaneetvelde@fundp.ac.be (corresponding author)

2 Géologie fondamentale et appliquée, Faculté Polytechnique de Mons, rue de Houdain, 9, B-7000 Mons, Belgium, christian.dupuis@hydro.fpms.ac.be

3 Département de géologie, F.U.N.D.P., 61 rue de Bruxelles, B-5000 Namur, Belgium, colette.cornet@fundp.ac.be

Manuscript received: February 2004; accepted: August 2004

\begin{abstract}
Assemblages of brackish and marine diatoms have been examined from Upper Paleocene-Lower Eocene strata of the Belgian Basin (Knokke well) and the Dieppe-Hampshire Basin (Saint-Josse borehole and Ailly sections). The diatoms observed are invariably preserved in pyrite as internal moulds and their siliceous skeletons are completely replaced by pyrite by epigenesis. Three major diatom assemblages have been observed which can be used to approximate the position of the recently defined Paleocene-Eocene boundary (defined by the Carbon Isotope Excursion). This isotope excursion occurs just below the strong increase in the abundance of Fenestrella antiqua and in the vicinity of the abundance peak of Coscinodiscus morsianus var. moelleri. They also allow correlations of the lithostratigraphic units of the Belgian Basin with the formations of the DieppeHampshire and central North Sea Basins. For instance, investigations of diatoms recorded in the Knokke Clay Member of the Knokke well indicate that this unit corresponds to the lower units of the 'Sparnacian facies' of the Dieppe-Hampshire Basin and to the Sele Formation of the North Sea Basin.
\end{abstract}

Keywords: Belgian Basin, diatoms, Paleocene-Eocene interval, Dieppe-Hampshire Basin, pyrite

\section{Introduction}

Several studies have shown that pyritized diatoms are well preserved and of biostratigraphic interest in the Paleogene sediments from the central North Sea Basin (e.g., Bidgood et al., 1999; Jacqué \& Thouvenin, 1975; King, 1983; Malm et al., 1984; Mitlehner, 1994, 1996; Mudge \& Copestake, 1992) and the Belgian Basin (King, 1983, 1990; Moorkens et al., 2000). In the Dieppe-Hampshire Basin, pyritized diatoms are known to be present in the Thanetian and Ypresian deposits (Bolin et al., 1982; Bignot, 1983) and their utility as key reference markers has been partially established (Van Eetvelde \& Cornet, 2002; Van Eetvelde \& Dupuis, 2004a, 2004b). In the Belgian Basin, the Knokke well has been previously analysed by King (1990) who studied the Eocene sediments and re-analysed by Moorkens et al. (2000) for its microand mega-fossil content in the Paleocene/Eocene boundary interval and also for its volcanic particles, clay-mineralogy and lithostratigraphy. Pyrite casts of diatoms (Fenestrella antiqua, Coscinodiscus morsianus var. morsianus and Trinacria regina) have been observed in the Tienen Formation and in the Kortrijk Formation. The Tienen Formation, a lateral equivalent of the mainly non-marine 'Sparnacian' s.s. succession of the Paris Basin, includes two main lithostratigraphic units (Steurbaut, 1998). The upper unit, the Oosthoek Sand Member is a probably shallow marine 'sand' bank type deposit with some dinocysts (Apectodinium hypercanthum zone) and diatoms observed in palynological preparations (Moorkens et al., 2000). These diatoms, being very poorly preserved, were not identified. The lower unit, the Knokke Clay Member is a 
brackish clay, i.e. a typical 'Sparnacian facies', with some twenty four thin intercalated shell beds (comprising five brackish water mollusc species and six brackish ostracod taxa) (Moorkens et al., 2000). No diatom flora has been observed in the Knokke Clay Member. Previous studies (Van Eetvelde \& Cornet, 2002; Van Eetvelde \& Dupuis, 2004a, 2004b) put in evidence the presence of very well preserved pyritized diatoms in 'Sparnacian' brackish clays intercalated with shell beds from the Dieppe-Hampshire Basin, a lateral equivalent of the Knokke Clay Member of the Knokke well. Knowing that sedimentary and environmental conditions prevailing during the deposit of the Knokke Clay Member and the 'Sparnacian' brackish clays were the same, it is strange that no diatoms have been observed in the Knokke Clay Member. Therefore during this study, samples of the Tienen Formation of the Knokke well have been re-analysed for their diatom content.

In this study, we have examined the biostratigraphic potential of pyritized diatom assemblages in the Late Paleocene-Early Eocene strata from the Belgian Basin (Knokke well) (Fig. 1). The assemblages recorded were also correlated with those observed in the central North Sea Basin and the Dieppe-Hampshire Basin (Saint-Josse borehole and Ailly sections) (Fig. 1). The other purpose of this work is the establishment of correlation of pyritized diatom assemblages with the new official Paleocene-Eocene boundary, defined by the Carbon Isotope Excursion (C.I.E.) (Luterbacher et al., 2000).

\section{Methods and materials}

Samples were taken in the Paleocene-Eocene transitional strata of the Knokke well (Fig. 1). Twenty-one samples were processed, three from the unnamed Sand Unit, ten from the Knokke Clay Member, two from the Oosthoek Sand Member, three from the Zoute Silt Member and three further samples from the Orchies Clay Member.

Separation of the pyritized diatoms from the sediments (clays, silts, shell beds, sands and marls) was carried out as described by Van Eetvelde \& Cornet (2002). Samples, once crushed were first treated with $\mathrm{HCl}$, and secondly with tetrasodiumdiphosphate to disperse the argillaceous component. Residues, after a granulometric sorting by sieving, were placed into bromoform which permits a density separation. The pyritized fraction, including the diatoms, settles down and can be collected. Diatoms were mounted on slides and counted under a microscope in transmitted and reflected lights. Diatoms were also examined with Scanning Electron Microscope (Philips XL-20) to confirm their identification.

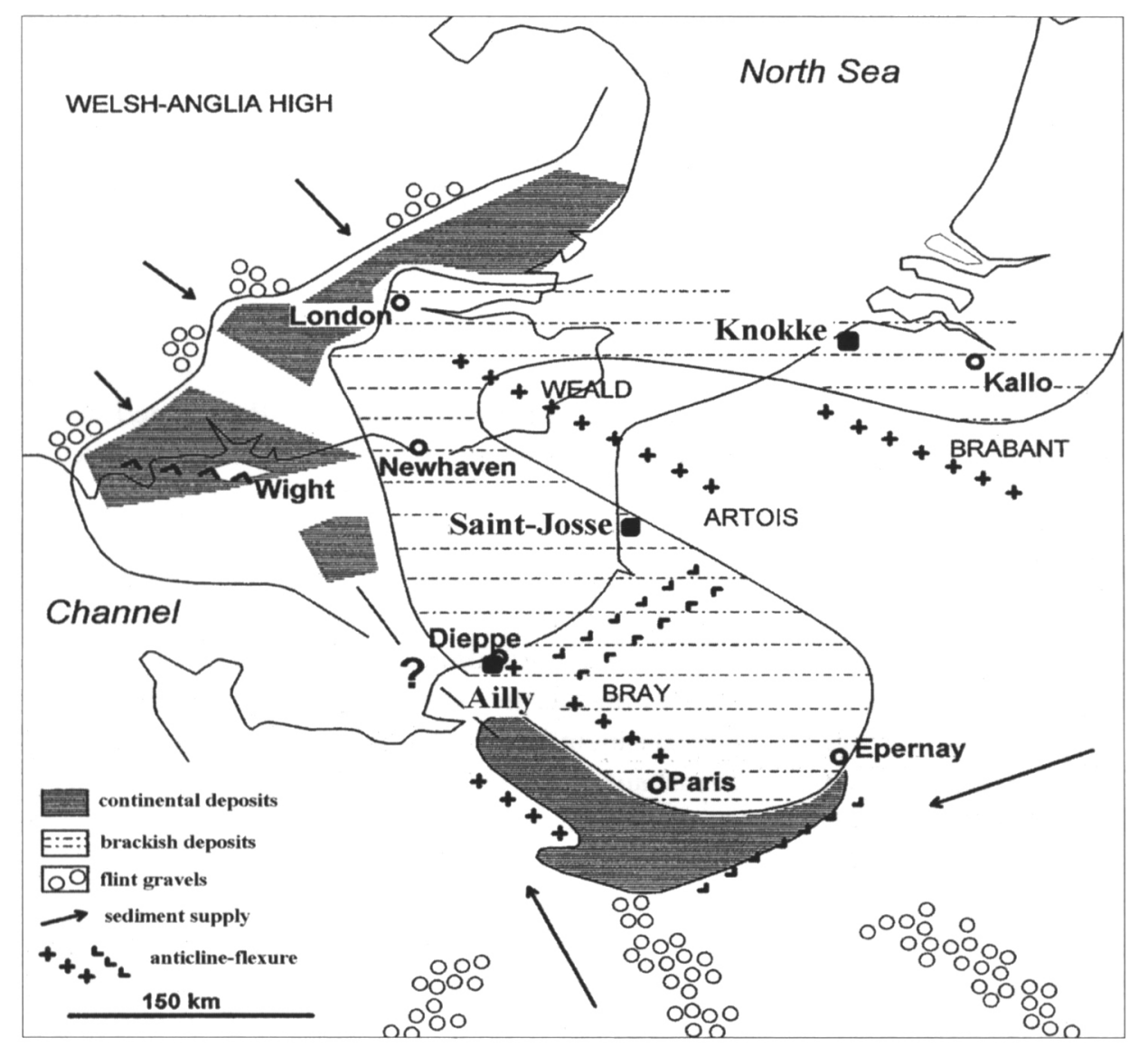

Fig. 1. Location map of Knokke, Ailly and Saint-Josse. Distribution of Paleogene facies in the southern part of the North Sea Basin (Modified after Dupuis et al., 1998). 


\section{Results and discussion}

The diatoms recorded in the sediments from the Belgian Basin are often preserved as internal moulds, constituted by pyrite crystals, of the space between the two siliceous frustules which comprise the test of the original specimen. The diatoms could be also completely pyritized by epigenesis; no unaltered siliceous individuals were observed. By X-ray microanalyses of the pyritized valves, it is proved that the original silica of the frustule of the diatoms is completely replaced by pyrite and that the internal moulds are only constituted by pyrite crystals. These two particular preservation styles of diatoms have already been observed in the Dieppe-Hampshire Basin (Bignot, 1983; Bolin et al., 1982; Van Eetvelde \& Cornet, 2002; Van Eetvelde \& Dupuis, 2004a, 2004b) and the central North Sea
Basin (Bidgood et al., 1999; King, 1983; Malm et al., 1984; Mitlehner, 1994, 1996; Mudge \& Copestake, 1992). Despite pyritization, diatoms recorded in the Knokke sediments are recognizable; brackish and marine species were observed but no fresh water specimens were encountered.

Using our methodology especially developed to extract pyritized diatoms (Van Eetvelde \& Cornet, 2002), a diatom assemblage is recorded in the Knokke Clay Member of the Knokke well, previously believed to be barren of diatoms (Dupuis et al., 1990; Moorkens et al., 2000). The diatom flora is rich and includes Actinoptychus senarius (a few), Coscinodiscus morsianus var. morsianus (common), Coscinodiscus morsianus var. moelleri (abundant), Odontella spp. (few), Hemiaulus elegans (few), Trinacria excavata (few) and Trinacria regina (few).

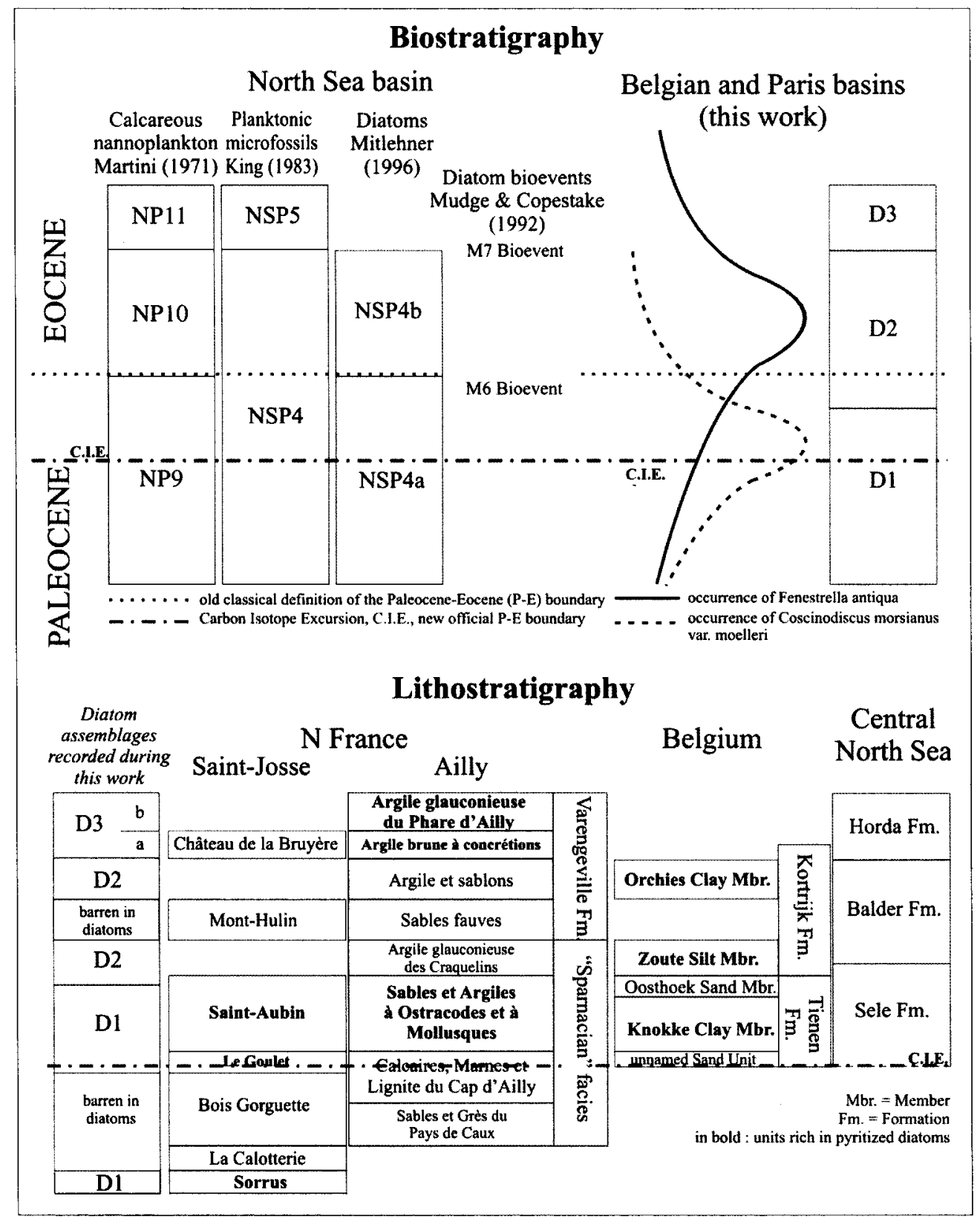

Fig. 2. Comparison of published latest Paleocene and earliest Eocene North Sea biozonations with diatom assemblages recorded in the Dieppe-Hampshire and Belgian Basins (this work). Correlations established by diatom age-datings between the lithostratigraphic units from the Belgian, DieppeHampshire and central North Sea Basins. 
Pyritized diatom assemblages change character through the stratigraphic sequence studied, with three successive diatom assemblages being defined, which provide a key reference marker for the PaleoceneEocene boundary sediments from the Belgian and Dieppe-Hampshire Basins (Fig. 2).

\section{Diatom Assemblage D1}

This assemblage is characterized by the presence of Trinacria regina (rare), Odontella sp. 1 (few), Hemiaulus elegans (few), Coscinodiscus morsianus var. morsianus (few) but mainly by the high percentage and the abundance peak of Coscinodiscus morsianus var. moelleri. In this diatom assemblage, Paralia siberica (not a marker species) can be found in the most 'continental' deposits. This assemblage is recorded in Thanetian and lower 'Sparnacian facies' deposits, more precisely in the Knokke Clay Member at Knokke, in the Sorrus, Le Goulet and lower part of the Saint-Aubin Units at Saint-Josse and in the lower 'Sables et Argiles à Ostracodes et à Mollusques' (S.A.O.M.) Unit at Ailly (Fig. 2).

\section{Diatom Assemblage D2}

This assemblage is defined by the abundance peak of Fenestrella antiqua, the decreased numbers of Coscinodiscus morsianus and a great diversity of circular diatoms. The upper part of this assemblage is marked by the highest abundance of Fenestrella antiqua. This assemblage corresponds to the upper part of the 'Sparnacian facies' and is found in the Zoute Silt Member and the Orchies Clay Member at Knokke, in the upper part of the Saint-Aubin Unit at Saint-Josse and in the upper S.A.O.M. Unit at Ailly (Fig. 2).

\section{Diatom Assemblage D3}

The youngest assemblage (D3), of lower Ypresian age, is characterized by the presence of Aulacodiscus spp., Trinacria spp., Triceratium spp., Craspedodiscus spp. and a high diversity of triangular, oval and bipolar species; these are held to indicate a marked increase in marine influence (Mitlehner, 1996). A distinction can be made between the lower (D3a) and upper part (D3b) of this assemblage. The $\mathrm{D} 3 \mathrm{~b}$ assemblage is characterized by the presence of three diagnostic taxa, Aulacodiscus sp. 3, Hemiaulus sp. 5 and Triceratium nobile, that are not recorded in the $\mathrm{D} 3 \mathrm{a}$ assemblage. This assemblage is only recorded in the 'Argile brune à concretions' and 'Argile glauconieuse du Phare d'Ailly' Units at Ailly (Fig. 2). No laterally equivalent strata were studied in the Knokke well.

\section{Stratigraphic correlations}

The changes in the Upper Paleocene-Lower Eocene diatom zonal assemblages, taxonomic composition, and ecological structure dynamics in the Belgian Basin are similar to those observed in the deposits of the Dieppe-Hampshire Basin (Van Eetvelde $\&$ Dupuis, 2004a, 2004b) and the central North Sea Basin (e.g. King, 1983, 1990; Mitlehner, 1994, 1996; Mudge \& Copestake, 1992). The diatom assemblages recorded in the Belgian and Dieppe-Hampshire Basins can be correlated with other biozonations established in the North Sea Basin, based on foraminiferids and diatoms (King, 1983), diatoms (Mitlehner, 1996) and calcareous nannoplankton (Martini, 1971) (Fig. 2). They allow also correlation of the lithostratigraphic units studied in the Belgian and Dieppe-Hampshire Basins with the Sele and Balder Formations of the central North Sea Basin which are known to be rich in diatoms (e.g. King, 1983; Mitlehner, 1996; Mudge \& Copestake, 1992) (Fig. 2). Fenestrella antiqua and Coscinodiscus morsianus var. moelleri are the more important diatom species encountered. Fenestrella antiqua (previously named Coscinodiscus sp. 1; King, 1983) is the fossil marker used by King to define his NSP4 biozone. The base of NSP4 corresponds to the lowest occurrence of Fenestrella antiqua and the top is marked by the highest occurrence of this species. Fenestrella antiqua and Coscinodiscus morsianus var. moelleri were also used by Mitlehner (1996) to differentiate the NSP4a zone (low abundance of Fenestrella antiqua and abundance of Coscinodiscus morsianus var. moelleri) from the NSP4b zone (great abundance and acme of Fenestrella antiqua). The high abundance of Coscinodiscus morsianus var. moelleri and the high abundance (including acme) of Fenestrella antiqua are respectively recorded in the Sele and Balder Formations.

Therefore, the Knokke Clay Member (Knokke well), the interval Sorrus/lower Saint-Aubin Units (SaintJosse borehole) and the lower S.A.O.M. Unit (Ailly sections) are correlated with the Sele Formation and the Orchies Clay Member (Knokke well) and the upper parts of Saint-Aubin (Saint-Josse borehole) and S.A.O.M. Units (Ailly sections) with the Balder Formation (Fig. 2). The Zoute Silt Member (Knokke well) is correlated with the upper part of the Sele Formation and the lower part of the Balder Formation. Other units studied are very poor or barren in diatoms and correlations are not possible by the comparison of the diatom assemblages.

Mudge \& Copestake (1992) described two major diatom bioevents during the Paleogene (Fig. 2). The first, $M 6$, bioevent is defined by the downhole acme of a distinctive diatom assemblage containing common 
to abundant Coscinodiscus morsianus var. morsianus, Coscinodiscus morsianus var. moelleri and resting spore of Fenestrella antiqua. This event is found in the Belgian and Dieppe-Hampshire Basins and corresponds to the boundary between the assemblages D1 and D2. It is recorded in the Zoute Silt Member at Knokke, in the Saint-Aubin Unit at Saint-Josse and in the 'S.A.O.M.' Unit at Ailly. The second, M7, bioevent is defined by a distinctive downhole diatom influx including Fenestrella antiqua and Coscinodiscus morsianus var. moelleri. This influx occurs within a rich and diverse diatom association, including species of Triceratium, Isthmia, Hemiaulus and Trinacria and corresponds to the upper boundary of the NSP4 biozone of King (1983). This bioevent is not found in the units studied.

The NSP4 biozone of King (1983) has approximately the same boundaries as our D2 diatom assemblage. The distinction is that the $\mathrm{D} 2$ diatom assemblage shows a higher diversity of species and a slightly different composition than the assemblage of NSP4 but it seems that some taxa, such as Actinoptychus senarius, are restricted in their paleogeographical occurrence, depending on the paleoenvironment. Actinoptychus senarius occurs in brackish paleoenvironments in the Belgian and Dieppe-Hampshire Basins and is rare in the central North Sea Basin. Further investigations in the Belgian and DieppeHampshire Basins must be necessary in order to clarify the influence of ecological controls.

\section{Paleocene-Eocene boundary}

The first peak abundance of Fenestrella antiqua was previously used to determine the base of the Eocene (Mitlehner, 1996) (Fig. 2) but the Paleocene-Eocene boundary used by Mitlehner was not the new official boundary defined by Luterbacher et al. (1998), i.e. the Carbon Isotope Excursion (C.I.E.). The correlation between the diatom assemblages and the C.I.E. was not yet realised in previous studies. The carbon isotope analyses have been realised in the sites located in the Dieppe-Hampshire Basin. They show the presence of the C.I.E. in the Lignite horizon L1 at the top of the 'Calcaires, Marnes et Lignites du Cap d'Ailly' Unit at Ailly (Magioncalda et al., 2001) and in the 'Le Goulet' Unit at Saint-Josse (Magioncalda \& Dupuis, in preparation). By correlating the diatom assemblages and the occurrences of some diatom species with the position of the C.I.E., we obtain the result that the official Paleocene-Eocene boundary is placed under the abundance peak of Fenestrella antiqua, in the vicinity of the high occurrence of Coscinodiscus morsianus var. moelleri (Fig. 2) and globally in the D1 assemblage or in the NSP4a of Mitlehner (1996) adapted from the NSP4 (King, 1983). In the Knokke well Moorkens et al. (2000) suggest, by dinocyst age-datings, that the lower part of the Knokke Clay Member must be younger than the C.I.E., when accepting that the isotope excursion occurred during the Apectodinium augustum and Apectodinium homomorphum acme zones. According to the idea, presented in this paper, that the C.I.E. occurred in the diatom assemblage characterized by the abundance of Coscinodiscus morsianus var. morsianus and Coscinodiscus morsianus var. moelleri, the Knokke Clay Member is younger than the C.I.E and then the isotope excursion is perhaps recorded in the paleosols of the unnamed sand unit. It confirms the results obtained by Moorkens et al. (2000) by dinocyst agedatings.

\section{Conclusions}

The present work has revealed that pyritized diatoms, despite wide variations in their preservation in the sediments, are suitable for correlations and biostratigraphical analyses in the Belgian, Dieppe-Hampshire and central North Sea Basins. Three major diatom assemblages have been recognised in the Belgian and Dieppe-Hampshire Basins. The lowermost, D1, occurs in the Knokke Clay Member (Belgian Basin), the interval Sorrus-Saint-Aubin (lower part) Units and lower 'Sables et Argiles à Ostracodes et Mollusques' (S.A.O.M.) Unit (Dieppe-Hampshire Basin). This assemblage is characterized by the abundance peak of Coscinodiscus morsianus var. moelleri. The second, most diverse assemblage (called D2), occurs in the Zoute Silt Member and the Orchies Clay Member (Belgian Basin), in the Saint-Aubin (upper part) and upper S.A.O.M. Units from the Sparnacian facies of the Dieppe-Hampshire Basin. The most abundant species recorded in this assemblage is Fenestrella antiqua. The last and most diverse assemblage (D3), including more cosmopolitan species (e.g., Craspedodiscus oblongus, Aulacodiscus spp.), is found in the Lower Ypresian units of the Dieppe-Hampshire Basin but was not observed in the Knokke well.

By diatom age-datings, the Knokke Clay Member, the interval Sorrus-lower part of Saint-Aubin Unit and lower S.A.O.M. Unit are correlated with the Sele Formation of the central North Sea Basin and the Orchies Clay Member, the upper S.A.O.M. and upper Saint-Aubin Units with the Balder Formation. The Zoute Silt Member is correlated with the upper part of the Sele Formation and the lower part of the Balder Formation. 
This work indicates that the best marker diatoms used to locate the C.I.E. are Coscinodiscus morsianus var. morsianus and overall Coscinodiscus morsianus var. moelleri which characterized the diatom assemblage D1 in the Belgian and Dieppe-Hampshire Basins. The C.I.E. occurs in the D1 diatom assemblage and is recorded just under the abundance peak of Coscinodiscus morsianus var. moelleri. When accepting this result observed in the Dieppe-Hampshire Basin, the C.I.E. can be expected in the base or in the lower part of the Tienen Formation in Belgium, as already shown by dinocyst age-datings (Moorkens et al., 2000).

\section{Acknowledgments}

This work was carried out as part of a $\mathrm{PhD}$ research project in the Geology Department of the Facultes Universitaires Notre-Dame de la Paix of Namur. We thank Professor V. Hallet for financial assistance and J-P. Debar of the Centre d'Etudes Techniques de l'Equipement Nord-Picardie who gave permission to use the samples of the Saint-Josse borehole CC82. We wish also to acknowledge J. Dagnelie for technical assistance with the treatment of the samples.

\section{References}

Bidgood, M.D., Mitlehner, A.G., Jones, G.D. \& Jutson, D.J., 1999. Towards a stable and agreed nomenclature for North Sea Tertiary diatom floras - the 'Coscinodiscus' problem. In: Jones, R.W. \& Simmons, M.D. (eds): Biostratigraphy in Production and Development Geology. Geological Society of London, Special Publication 152: 139-153.

Bignot, G., 1983. Les Lagunes Sparnaciennes: Une étape dans la conquête des eaux douces par les diatomées. Revue de micropaléontologie 26: 15-21.

Bolin, C., Tourenq, J. \& Ambroise, D., 1982. Sédimentologie et microfossiles pyritisés du sondage de Cuise-la-Motte (Bassin de Paris). Bulletin d'Information des Géologues du Bassin de Paris 19: 55-65.

Dupuis, C., De Coninck, J., Guernet, C. \& Roche, E., 1990. Biostratigraphic data - ostracods and organic walled microfossils - of the Landen Formation and the base of the Ieper Formation in the Knokke borehole. In: Laga, P. \& Vandenberghe, N. (eds): The Knokke well (11E/138) with a description of the Den Haan $(22 \mathrm{~W} / 276)$ and Oostduinkerke (35E/142) wells. Mémoires pour servir à l'Explication des Cartes Géologiques et Minières de la Belgique 29: 33-43.

Dupuis, C. \& Thiry, M., 1998. Geological frame of the 'Sparnacian'. In: Thiry, M. \& Dupuis, C. (eds): The Palaeocene/Eocene boundary in the Paris Basin: the Sparnacian deposits. Field trip guide, Mémoires Sciences de la Terre, Ecole des Mines de Paris 34: 3-12.

Jacqué, M. \& Thouvenin, J., 1975. Lower Tertiary tuffs and volcanic activity in the North Sea. In: Woodland, A.W. (ed): Petroleum and the Continental Shelf of Northwest Europe, Volume 1: Geology. Applied Science Publishers (Barking): 455-465.
King, C., 1983. Cainozoic Micropalaeontological Biostratigraphy of the North Sea. Institute of Geological Sciences. Report 82/7. HMSO (London): $40 \mathrm{pp}$.

King, C., 1990. Eocene stratigraphy of the Knokke borehole (Belgium). In: Laga, P. \& Vandenberghe, N. (eds): The Knokke well (11E/138) with a Description of the Den Haan (22W/276) and Oostduinkerke (35E/142) Wells. Mémoires pour servir à l'Explication des Cartes Géologiques et Minières de la Belgique 29: 67-102.

Luterbacher, H.P., Hardenbol, J. \& Schmitz, B., 2000. Decision of the Voting Members of the International Subcommission on Paleogene Stratigraphy on the Criterion for the Recognition of the Paleocene/Eocene Boundary. Newsletter International Subcommission on Paleogene Stratigraphy 9: 13.

Magioncalda, R., Dupuis, C., Blamoart, D., Fairon-Demaret, M., Perreau, M., Renard, M., Riveline, J., Roche, M. \& Keppens, E., 2001 . L'excursion isotopique du carbone organique ( $\delta 13 \mathrm{Corg}$ ) dans les paléoenvironnements continentaux de l'intervalle Paléocène-Eocène de Varengeville (Haute-Normandie). Société géologique de la France 172: 349-358.

Malm, O.A., Christensen, O.B., Furnes, H., Lovlie, R., Ruselåtten, H. \& Østby, K.L., 1984. The Lower Tertiary Balder Formation: an organogenic and tuffaceous deposit in the North Sea region. In: Spencer, A.M. (ed): Petroleum Geology of the North European Margin. Graham \& Trotman (London): 149-170.

Martini, E., 1971. Standard Tertiary and Quaternary calcareous nannoplankton zonation. In: Farinacci, A. (ed): Proceedings of the II Planktonic Conference, Tecnoscienza 2: 739-785.

Mitlehner, A.G., 1994. The occurrence and preservation of diatoms in the Palaeogene of the North Sea Basin. PhD Thesis (University of London): $278 \mathrm{pp}$.

Mitlehner, A.G., 1996. Palaeoenvironments in the North Sea Basin around the Palaeocene-Eocene boundary: evidence from diatoms and other siliceous microfossils. In: Knox, R.W.O'B., Corfield, R.M. \& Dunay, R.E. (eds): Correlation of the Early Paleogene in Northwest Europe. Geological Society of London, Special Publication 101: 255-273.

Moorkens, T., Steurbaut, E., Jutson, D. \& Dupuis, C., 2000. The Knokke borehole of NW Begium re-analysed: new data on the Palaeocene-Eocene transitional strata in the southern North Sea Basin. GFF, 122: 111-114.

Mudge, D.C. \& Copestake, P., 1992. Lower Palaeogene stratigraphy of the northern North Sea. Marine and Petroleum Geology 9: 287-301.

Steurbaut, E., 1998. High-resolution holostratigraphy of Middle Paleocene to Early Eocene strata in Belgium and adjacent areas. Palaeontographica Abt. A 247: 91-156.

Van Eetvelde, Y. \& Cornet, C., 2002. Some Eocene species of marine pyritized diatoms in the core of Saint-Josse (France). Diatom Research 17: 423-435.

Van Eetvelde, Y. \& Dupuis, C., 2004a. Upper Paleocene and Lower Eocene interval in the Dieppe-Hampshire Basin: biostratigraphic analysis based on pyritized diatoms. Geological Society, Special Publication, under press.

Van Eetvelde, Y. \& Dupuis, C., 2004b. Biostratigraphical and paleoenvironmental study based on pyritized diatoms of the Upper Paleocene-Lower Eocene interval of the Saint-Josse core (France). Geobios, accepted for publication. 